\title{
Alkali-Silica Reaction Potential of Arc-related Volcanic Rocks from the Göksun Ophiolite (Kahramanmaraş-Turkey)
}

\section{Tamer Rızaoğlu}

Kahramanmaraş Sütçü Imam University, Department of Geological Engineering, 46100, Kahramanmaraş e-mail: tamer@ksu.edu.tr

Keywords Ophiolite; volcanic; aggregate; Alkali-silica reactivity;

Accelerated mortar bar method

\begin{abstract}
The alkali-silica reactivity is one of the most important problems that can occur in concrete structures. Because of their wide spectrum of mineralogical compositions and phases, volcanic rocks are more likely to cause alkali-silica reactivity. In this study, alkali-silica reactivity potentials of the rocks representing the upper levels of the crustal section of the Late Cretaceous suprasubduction-type Göksun ophiolite in the Tauride ophiolitic belt have been investigated. The Göksun ophiolite displays and intact ophiolite pseudostratigraphy with the thick layer of volcanic section characterized by a different composition of rock units such as basalt, basaltic-andesite, andesite, dacite and rhyolite. Firstly, the petrographic determinations of the samples derived from these volcanic units were made and then geochemical analyzes carried out on the same specimens to control the accuracy of the petrographic analyzes and the rocks were classified according to trace elements. Finally, the accelerated mortar bar method was applied on the concrete bars produced from same rock samples to compare the variation of Alkali-Silica Reactivity (ASR) with lithology. The test results yielded that the intermediate volcanics have much Alkali Silica Reactivity (ASR) potential than basic and acidic volcanics (basalts, rhyolites and dacites). It is estimated that the glassy matrix of the intermediate volcanics is partly responsible for the alkali-silica reactivity. $\mathrm{SiO}_{2}, \mathrm{TiO}_{2}, \mathrm{Al}_{2} \mathrm{O}_{3}, \mathrm{Na}_{2} \mathrm{O}$ and $\mathrm{K}_{2} \mathrm{O}$ values have show positive correlation with the amounts of expansion in the andesite and basaltic andesites, whereas the major oxide contents of acidic and basic volcanic rocks have no clear relation with the expansion ratios.
\end{abstract}

\section{Göksun Ofiyolitine ait (Kahramanmaraş-Türkiye) Yayla ilişkili Volkanik Kayaçların Alkali-Silika Reaksiyonu Potansiyeli}

\begin{abstract}
Alkali-silika reaktivitesi beton yapılarda en önemli problemlerden birisidir. Geniş spektrumlu mineralojik bileşimleri ve fazları dolayısıyla volkanik kayaçlar alkali-silika reaktivitesine daha meyillidirler. Bu çalışmada, Toros ofiyolit kuşağında yer alan Geç Kretase yaşlı okyanus içi dalma-batma zonu üzerinde oluşan Göksun ofiyoliti'nin kabuk bölümünün üst seviyelerini temsil eden kayaçların alkali-silika reaktivite potansiyeli araştırımıştır. Göksun ofiyoliti bazalt, bazaltik andezit, andezit, dasit ve riyolit gibi farklı bileşimde kayaçlarla temsil edilen kalın bir volkanik seviyeyle beraber tam bir ofiyolit istifi sunmaktadır. Bu volkanik birimlerden derlenen örneklerin öncelikle petrografik determinasyonları yapılmış, daha sonra petrografik analizlerin doğruluğunu kontrol etmek için aynı örnekler üzerinde yapılan jeokimyasal analizler kullanılarak kayaçların iz elementlere dayalı olarak sınıflandırılması yapılmştır. En sonunda da örneklerden elde edilen agregalarla üretilen beton çubuklara bu kayaçların litolojileri ile Alkali-Silika reaktivitesi (ASR) değişimini karşılaştırmak üzere hızlandırılmış harç çubuğu metodu testi uygulanmıştır. Test sonuçları ortaç volkaniklerin (andezit ve bazaltik andezit) bazik ve asidik volkaniklere (bazalt, riyolit ve dasit) nazaran daha yüksek Alkali Silica Reaktivitesi (ASR) potansiyeline sahip olduğunu göstermektedirler. Ortaç volkaniklerin camsı matrisinin alkali-silika reaktivitesinden kısmen sorumlu olduğu tahmin edilmektedir. $\mathrm{SiO}_{2}, \mathrm{TiO}_{2}, \mathrm{Al}_{2} \mathrm{O}_{3}, \mathrm{Na}_{2} \mathrm{O}$ ve $\mathrm{K}_{2} \mathrm{O}$ değerleri, andezit ve bazaltik andezitlerdeki genleşme miktarı ile pozitif korelasyon gösterirken, asidik ve bazik volkanik kayaçların ana oksit içeriği, genleşme oranları ile açık bir ilişkiye sahip değildir.
\end{abstract}




\section{Introduction}

Alkali silica reaction (ASR) is a kind of chemical reaction between some specific reactive minerals existing in the aggregates and alkalis in the pore solution of concrete (Farny and Kerkhoff, 2007). This reaction is harmful only when it causes the certain amount of expansion that force the concrete, loss in mechanical properties and turned into the gel form weaken the concrete. Damage occurred in concrete due to ASR (Alkali-silica reaction) was first recognized in the United States in 1940 and since then although many scientist have been continuing to search the mechanism, it was not clearly unfolded. To detect the Alkali-silica reactivity potential of the aggregates earlier than investment and use in concrete will help the engineers and builders by saving in repair and maintenance costs and increase the service life of the structure.

For pointing out the effect of the mineralogical composition, lithology and alteration on ASR potential, a number of studied carried out: Grattan-Bellew et al., 1998 prepared mortar bars made with basalt, dolostone, granite, limestone, and pure crystalline quartz aggregates to test the effect of aggregate composition on ASR capacity and stated that the composition of the fine aggregate has a marked effect on the amount of expansion and the amount of etringite formed. Shahidul Islam and Akhtar, 2013 implied that pure dolomite and limestone rocks can be considered as harmless, whereas silicious rocks, dolomiticlimestone, volcanic rocks such as andesite, basalt, dacite, rhyolite and chert, opal, quartz minerals are prone to alkali-silica reactions. Mineralogy of aggregate is unable to detect the extent of Alkali silica reactivity potential (Shahidul Islam and Akhtar, 2013; Çopuroğlu et al., 2009) and a concrete aggregate might contain a small amount of reactive silica in any form which may not chemically determined (Shahidul Islam and Akhtar, 2013). Wakizaka, 2000 performed both the chemical and mortar bar methods for pointing out the effect of lithology on alkali-silika reaction. The results of both methods (the chemical and mortar bar methods) on the rocks from quarries and outcrops in Japan indicated the same results showing the reactive rocks were basalt, andesite, dacite, rhyolite, sandstone, shale, slate, tuffs, chert and quartz schist. The cristobalite, tridymite and volcanic glass are the most important agents on the production of alkali-silica reaction in the concretes produced from volcanic rocks (Wakizaka, 2000). The effect of volcanic glass on ASR was pointed out several other studies (Marfil and Maiza, 2001, St John, 1988, Korkanç and Tuğrul, 2005). Katayama et al., 1989 and Korkanç and Tuğrul implied that the silica content of the volcanic rocks is a very important element for ASR production. Katayama et al., 1989 also pointed out the importance of the silica content of basalt by means of ASR potential and indicated that the basalts having more than $50 \%$ of silica should be accepted as if its lithology is andesite in the ASR point of view.

The aim of this paper is to present the alkali-silika reactivity potential of the different lithological units of the volcanic section of the Göksun ophiolite by using the accelerated mortar bar method.

\section{Geology of The Study Area}

The southeast Anatolian orogenic activity in the northern part of Kahramanmaraş have roughly east-west trending three different zone namely: the nappe zone, the zone of imbrication and the Arabian platform (Yılmaz, 1990, 1993; Yılmaz et al., 1993). The nappe zone represents the highest levels and are divided into two different sub-units as the lower and upper nappe zones (Yılmaz, 1993). The lower nappe zone is represented by the late Cretaceous ophiolitic units (remnants of the oceanic crust) and Maden complex. The upper nappe zone includes metamorphic platform carbonates (Ketin, 1983; Yılmaz, 1993).

The late Cretaceous Göksun ophiolite is seen in a tectonic window surrounded by Malatya metamorphics both from north and south is located in the East-West trending nappe zone (upper nappe zone) of the southeast Anatolian orogenic belt (Yılmaz,1993) in the area between Göksun and Afşin (Kahramanmaraş) (Figure 1) (Parlak et al., 2004; Rızaoğlu et al., 2005). The Göksun ophiolite representing the lower nappe zone of the southeast Anatolian orogenic belt (Yılmaz,1993) is characterized by a complete ophiolitic pseudostratigraphy, from bottom to top, 
tectonites, ultramafic to mafic cumulates, isotropic gabbro, sheeted dike complex, plagiogranite and volcanic units (Figure 1). The ophiolitic rocks and the tectonically overlying Paleozoic Malatya metamorphics were intruded by a syn-collisional late Cretaceous Esence granitoid (Rızaoğlu et al.,
2005)(Figure 1). The volcanic rocks representing the higher level of the general suite of Göksun ophiolite are characterized by a wide spectrum of rocks from basic to acidic rock association. They are seen at different stratigraphic levels in the S-SE of the study area (see Fig. 1).
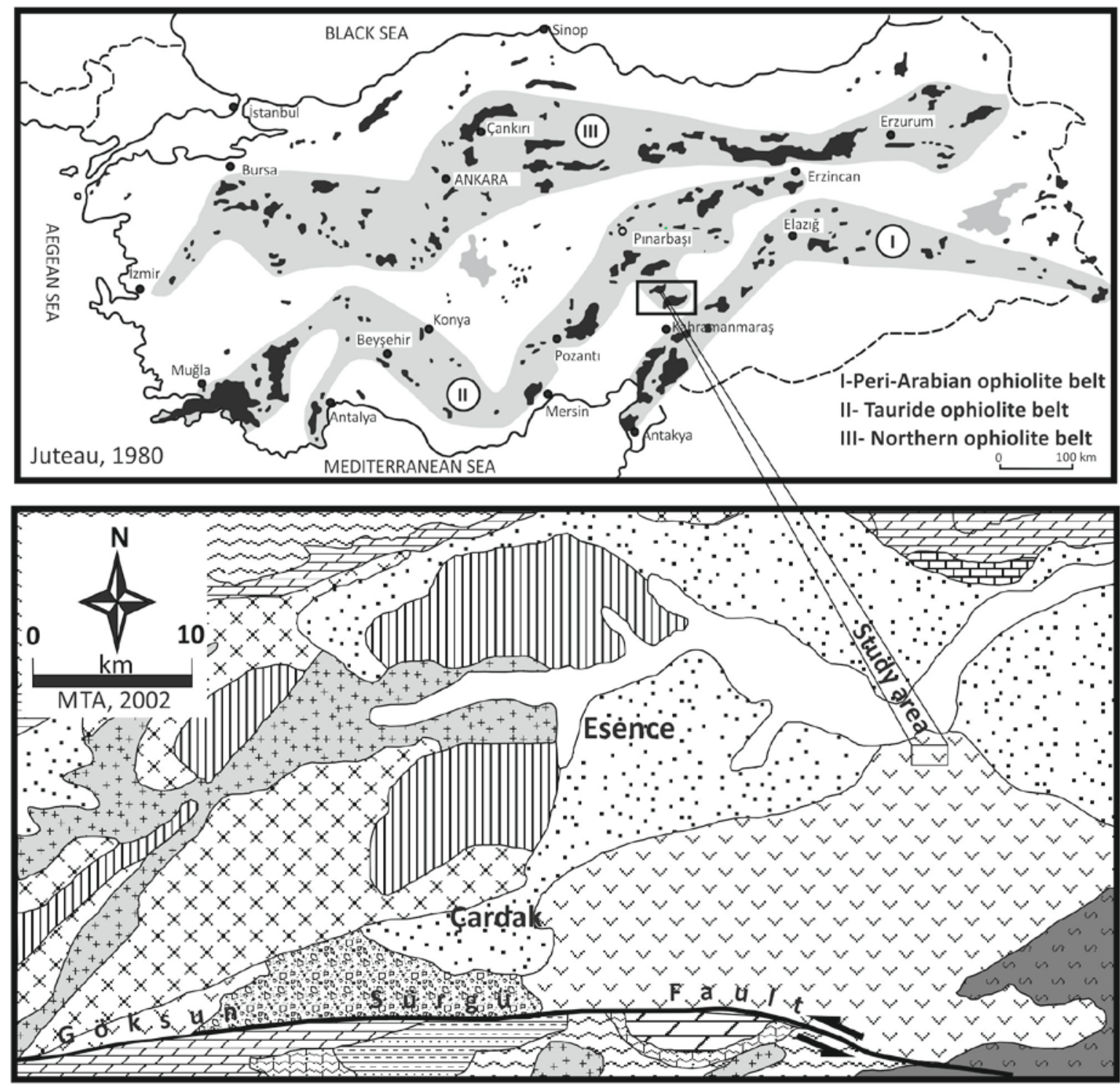

\section{LEGEND}

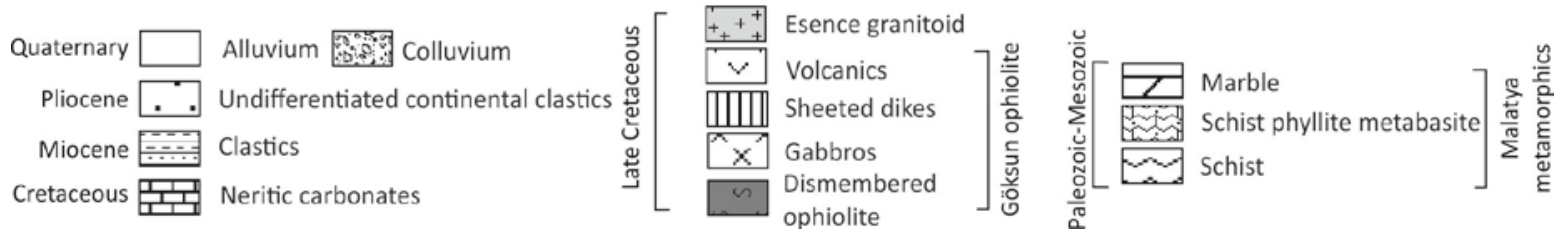

Figure 1. Geological map of the study area (MTA, 2002 and The ophiolite belts of Turkey map is from Juteau,1980)

\section{Materials and Methods}

The volcanic section of the late Cretaceous Göksun ophiolite covers a wide outcrops in the study area (Figure 1). Due to difference of their composition, the volcanics are seen in different colours in the field. Firstly, a total of 13 samples from the volcanics representing the upper level of Göksun ophiolite were collected from the field by taking care of their visible mineral compositions and colour. Then petrographic determination studies 
were performed under a polarizing microscope Nikon Eclipse 50i POL, with digital camera CLEMEX. The textural and mineralogical characteristics of the volcanic rocks were identified and then the photomicrographs of the important elements were obtained by using its soft ware (StCamSware).

The second stage was geochemical analyses. Major and trace elements of the samples were analyzed at Pamukkale University, Department of Geology by a Spectro XEPOS Polarized Energy Dispersive $X$-RF(PEDXRF) using a $50 \mathrm{~W}$ Pd end window X-ray tube. The spectral resolution of this detector is 160 $\mathrm{eV}$ for $\mathrm{Mn} \mathrm{K \alpha}$. For the XRF analyses, the samples were crushed in a tungsten carbide crushing vessel, and $6.25 \mathrm{~g}$ of powdered sample was mixed with 1.4 $\mathrm{g}$ of wax. The rock powder and wax mixture was pressed at $20 \mathrm{~N}$ in an automatic press to obtain a disc for analysing. The last stage of the study was applying the accelerated mortar bar method ASR testing on the samples that were selected and groupped into their lithology and prepared a mortar by mixing with the CEM 1-type portland cement (Figure 2a Table 1) The mortar bars prepared from those mortar by pouring the into the mould (Figure 2b). The bars were taken from mould after 24 hours keeping in the room temperature (Figure 2c). The size of the mortar bars is $25 \times 25 \times 285 \mathrm{~mm}$. The expansion of each bars were measured after remoulded. Then they were put into the bath filled with $\mathrm{NaOH}$ solution at a constant temperature $\left(80^{\circ} \mathrm{C}\right)$ (Figure $2 \mathrm{~d}$ ). At the end of 14 days, the bars were measured again for comparing the difference between first and last dimensions with the ASTM C-1260 standard (Figure 2e).
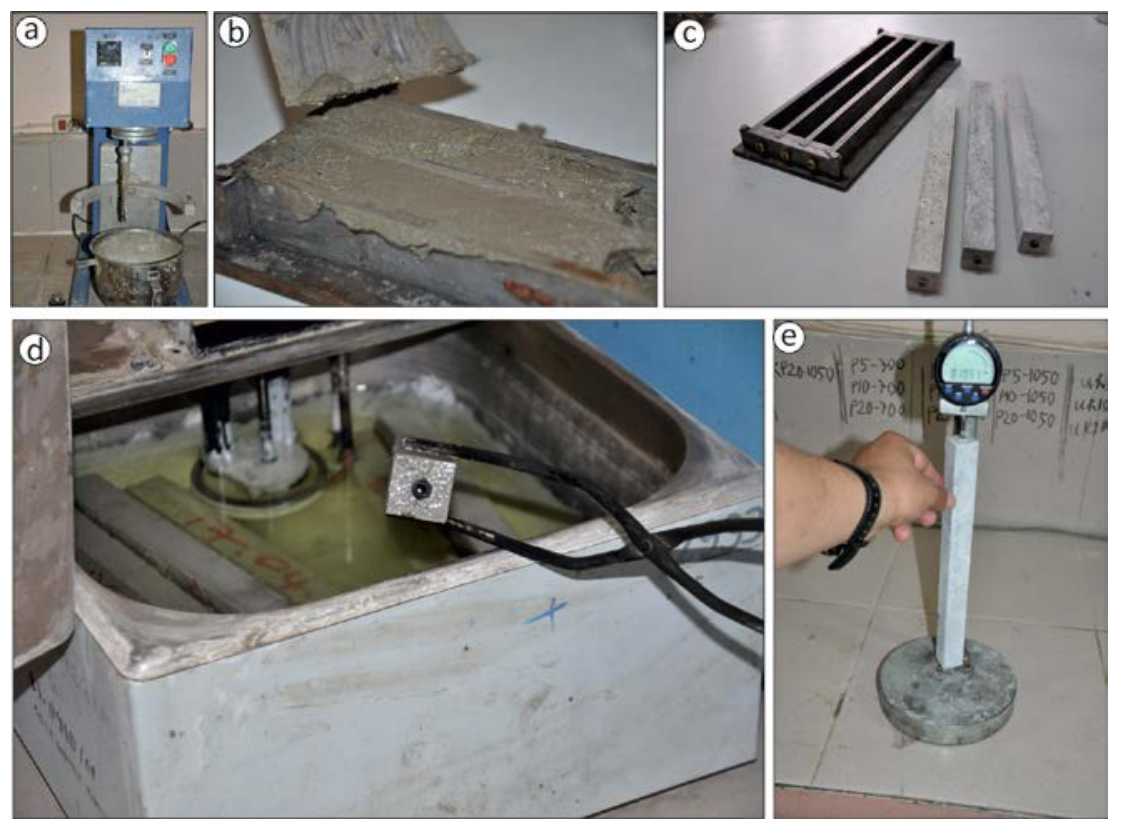

Figure 2. The stages of ASR testing with accelerated mortar bar method a) mortar preparation b) molding c) removing bars from the mold d) $\mathrm{NaOH}$ bath e) measurement of bars

Table 1. Chemical composition of portland CEM-1 cement (Binici et al., 2013)

\begin{tabular}{lccccccccc}
\hline Oxides (\%) & $\mathrm{SiO}_{2}$ & $\mathrm{Al}_{2} \mathrm{O}_{3}$ & $\mathrm{Fe}_{2} \mathrm{O}_{3}$ & $\mathrm{CaO}$ & $\mathrm{MgO}$ & $\mathrm{Na}_{2} \mathrm{O}+\mathrm{K}_{2} \mathrm{O}$ & $\mathrm{SO}_{3}$ & Free $\mathrm{CaO}$ & \multicolumn{1}{l}{ LOI } \\
\hline Analyses & 18,55 & 4,80 & 2,40 & 62,80 & 2,50 & 1,14 & 3,69 & 0,90 & 3,50 \\
\hline
\end{tabular}

\section{Results}

\subsection{Petrography}

Pillow lavas are the general form of the basic volcanics, whereas the intermediate and acidic volcanics generally crop out as lava flows. Different alteration colours are the most important elements for pre-estimating the composition of the volcanics before geochemical and petrographical studies (Figure 3). Basalts and basaltic andesites are always dark in colour (Figure 3a). The andesitic rocks are greenish to brown in colour and seen in the form of lava flow in the field (Figure $3 b$ ). The acidic rocks of 
the volcanic units are represented by Rhyolite and Dacite. They are white to grey in colour with the form of lava flow (Figure 3c). All those rock units are located in a narrow area, where as the rest of the volcanic area dominant in basalt.

The basaltic rocks which are characterized by dark colored pillow shaped lava flows in the field display intersertal, microlitic porphyric, vesicular and amygdaloidal textures. They are mainly composed of plagioclase minerals with the form of microliths and phenocrysts as an indication of two stages of cooling history. The minor amount of pyroxene minerals accompanying with the secondary alteration mineral association such as albite, chlorite, epidote and calcite form the rest of the mineral composition. The calcite, epidote and chlorite are the filler material of the pore spaces resulting with the formation of amygdaloidal texture (Figure 4b). The basaltic andesites exhibit intersertal, microlitic, microlitic porphyric and amygdaloidal texture (Figure 4c) and are generally composed of plagioclase and clinopyroxene as primary mineral phases. Epidote, chlorite and calcite form the secondary alteration mineral assemblage.

The andesites present intersertal and microlitic porphyric texture (Figure 4d). Plagioclase represents the most abundant mineral accompanied by minor amount of hornblende phenocrists. Epidote, chlorite and calcite form the secondary alteration phases in the andesites.
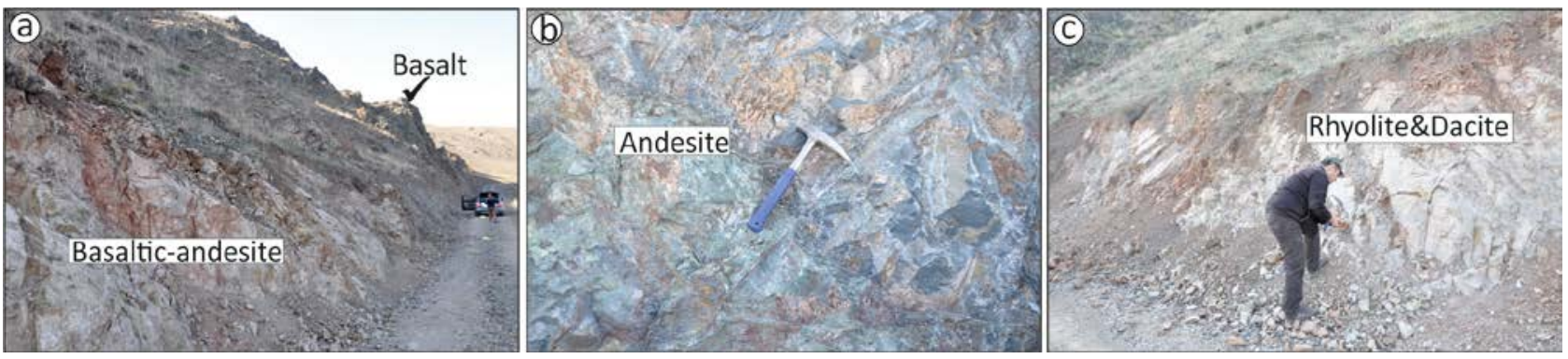

Figure 3. Field views from the volcanic rocks of the Göksun ophiolite
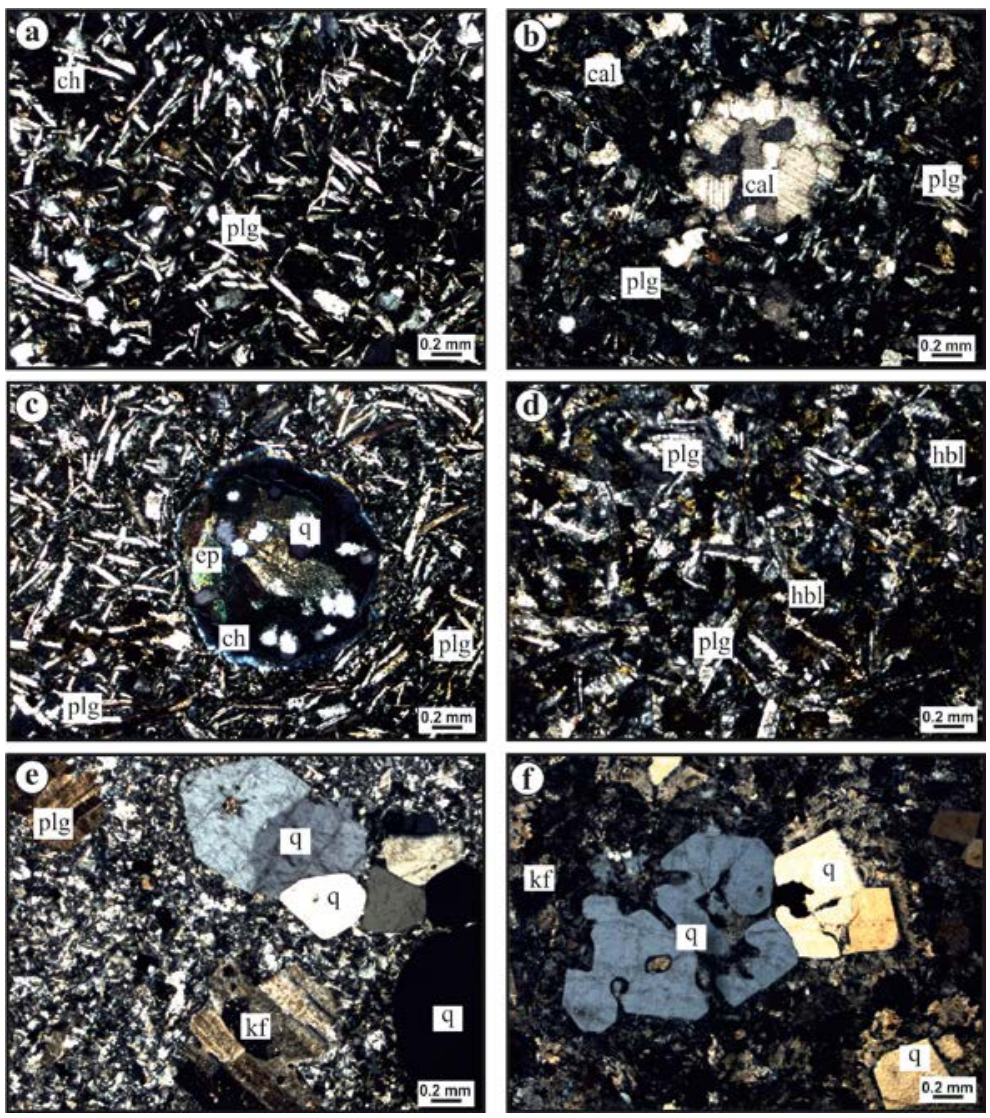
Figure 4. a) Intersertal texture in basalt b) amygdaloidal texture in basalt c) amygdaloidal texture in basaltic andesite d) Intersertal texture in andesite e) Microlitic porphyric texture in Rhyolite f) Corroded quartz crystals and porphyric texture in dacite. Abbreviations; $k f$ : k-feldspar, plg: plagioclase, q: quartz, $h b l:$ hornblende, ep: epidote, ch: chlorite, cal:calcite

The rhyolitic volcanic rocks display microlitic porphyric and hyalo-microlitic porphyric textures and are represented by corroded idiomorphic or sub-idiomorphic quartz crystals together with plagioclase phenocrysts dispersed in a groundmass which is composed of K-feldspar and plagioclase microcrystals (Figure 4e).

The dacitic volcanic rocks display microlitic porphyric to glomeroporphyric textures (Figure 4f). The plagioclases are reflecting the products of two different cooling times as microlitic and phenocrysts and are the first abundant mineral in these rocks. The second abundant mineral phase is quartz crystals and are generally seen as phenocrysts. They exhibit the traces of secondary magma injection as displaying corroded borders as a result of hot magma injection. The secondary alteration minerals are represented by extensive epidote, chlorite and rare calcite.

\subsection{Geochemistry}

Major and trace element contents of a total of 13 samples from the volcanic section of Late Cretaceous suprasubduction-type Göksun ophiolite were analysed (Table 2).

Table 2. Major and minor element analysis of the volcanic rocks from the Göksun ophiolite

\begin{tabular}{|c|c|c|c|c|c|c|c|c|c|c|c|c|c|}
\hline & \multicolumn{2}{|c|}{ Basalt } & \multicolumn{4}{|c|}{ Basaltic andesite } & \multicolumn{2}{|c|}{ Andesite } & \multicolumn{4}{|c|}{ Rhyolite } & \multirow{2}{*}{$\begin{array}{c}\text { Dacite } \\
\text { T22 }\end{array}$} \\
\hline & T-9 & T-13 & T-4 & T-7 & T-18 & T-21 & T2 & T20 & T14 & T17 & T23 & T24 & \\
\hline $\mathrm{SiO}_{2}$ & 44,21 & 50,31 & 50,67 & 50,99 & 46,63 & 43,92 & 51,28 & 49,38 & 73,66 & 59,76 & 68,36 & 70,74 & 59,03 \\
\hline $\mathrm{TiO}_{2}$ & 1,62 & 1,53 & 1,62 & 1,64 & 1,32 & 1,39 & 1,64 & 1,22 & 0,33 & 0,21 & 0,23 & 0,24 & 0,26 \\
\hline $\mathrm{Al}_{2} \mathrm{O}_{3}$ & 12,80 & 13,69 & 15,30 & 15,46 & 14,21 & 13,92 & 15,48 & 13,26 & 13,35 & 10,99 & 12,96 & 12,74 & 17,42 \\
\hline FeO* & 11,44 & 10,05 & 9,74 & 9,87 & 10,13 & 10,20 & 9,84 & 9,86 & 3,33 & 1,91 & 2,00 & 1,13 & 1,80 \\
\hline MnO & 0,22 & 0,12 & 0,17 & 0,17 & 0,21 & 0,13 & 0,17 & 0,12 & 0,07 & 0,05 & 0,03 & 0,03 & 0,05 \\
\hline MgO & 8,08 & 7,22 & 6,86 & 7,04 & 10,98 & 8,48 & 6,95 & 6,23 & 0,95 & 0,40 & 0,38 & 0,38 & 0,47 \\
\hline $\mathrm{CaO}$ & 3,98 & 3,73 & 3,92 & 3,99 & 5,29 & 5,72 & 3,96 & 2,68 & 0,24 & 3,25 & 2,27 & 1,74 & 3,20 \\
\hline $\mathrm{Na}_{2} \mathrm{O}$ & 3,16 & 4,79 & 4,45 & 4,56 & 2,86 & 2,68 & 4,44 & 3,86 & 6,48 & 3,72 & 5,51 & 4,22 & 0,27 \\
\hline $\mathrm{K}_{2} \mathrm{O}$ & 0,03 & 0,03 & 0,09 & 0,09 & 0,07 & 0,04 & 0,09 & 0,05 & 0,11 & 0,34 & 0,23 & 0,37 & 0,38 \\
\hline $\mathrm{P}_{2} \mathrm{O}_{5}$ & 0,15 & 0,17 & 0,22 & 0,22 & 0,12 & 0,17 & 0,22 & 0,20 & 0,07 & 0,04 & 0,05 & 0,05 & 0,07 \\
\hline $\mathbf{N b}$ & 2,20 & 2,10 & 2,60 & 3,50 & 1,10 & 1,00 & 3,10 & 1,70 & 3,20 & 2,50 & 1,40 & 1,30 & 1,20 \\
\hline $\mathrm{Zr}$ & 109,20 & 98,80 & 149,30 & 146,30 & 88,80 & 123,30 & 148,10 & 179,30 & 156,10 & 158,20 & 175,10 & 182,70 & 177,40 \\
\hline $\mathbf{Y}$ & 34,50 & 30,90 & 41,50 & 41,80 & 31,30 & 35,90 & 41,50 & 50,80 & 46,60 & 50,90 & 47,60 & 46,40 & 46,80 \\
\hline
\end{tabular}

The arc-related volcanic rocks representing the upper level of Göksun ophiolite are characterized by wide range of lithological units from basic to acidic based on their $\mathrm{Zr} / \mathrm{Ti}$ and $\mathrm{Nb} / \mathrm{Y}$ ratios (Figure 5, after Pearce, 1996).

The basic (mafic) group is represented by 44.2150.31\% $\mathrm{SiO}_{2}, 1.53-1.62 \% \mathrm{TiO}_{2}, 98.8-109.2 \mathrm{ppm} \mathrm{Zr}$, 30,90-34,50 ppm Y, 2.1-2.2 ppm Nb, 3.19-4.82 \% total alkali $\left(\mathrm{Na}_{2} \mathrm{O}+\mathrm{K}_{2} \mathrm{O}\right)$ content and classified as basalt (Figure 5; Table 2).
The basic-intermediate group is is characterized by 43.92-50.99\% $\mathrm{SiO}_{2}, 1.32-1.64 \% \mathrm{TiO}_{2}$, 88.8149.3ppm Zr, 31.3-41.8 ppm Y, 1.0-3.50 ppm Nb, 2.71-4.65 \% total alkali $\left(\mathrm{Na}_{2} \mathrm{O}+\mathrm{K}_{2} \mathrm{O}\right)$ content and plotted in basaltic-andesite field (Figure 5; Table 2). The other group is characterized by intermediate rocks and chemically has 49.38-51.28 \% $\mathrm{SiO}_{2}, 1.22-$ 1.64 \% $\mathrm{TiO}_{2}, 148.1-179.3$ ppm Zr, 41.5-50.8 ppm Y, 1.7-3.1 ppm Nb, 3.91-4.53 \% total alkali $\left(\mathrm{Na}_{2} \mathrm{O}+\mathrm{K}_{2} \mathrm{O}\right)$ content and is represented by andesite (Figure . 5; Table 2). 
The acidic group is characterized by rhyolite (Figure 5) with 59.76-73.66 \% $\mathrm{SiO}_{2}, 0.21-0.33 \% \mathrm{TiO}_{2}$, 156.1-182.7 ppm Zr, 46.4-50.9 ppm Y, 1.3-3.2 ppm $\mathrm{Nb}, 4.05-6.59 \%$ total alkali $\left(\mathrm{Na}_{2} \mathrm{O}+\mathrm{K}_{2} \mathrm{O}\right)$ content;
(Table 2) and dacite (Figure 5) with by $59.03 \%$ $\mathrm{SiO}_{2}, 0.26 \% \mathrm{TiO}_{2}, 177.4 \mathrm{ppm} \mathrm{Zr}, 46.80 \mathrm{ppm} \mathrm{Y}, 1.20$ ppm $\mathrm{Nb}, 0.65 \%$ total alkali $\left(\mathrm{Na}_{2} \mathrm{O}+\mathrm{K}_{2} \mathrm{O}\right)$ content (Table

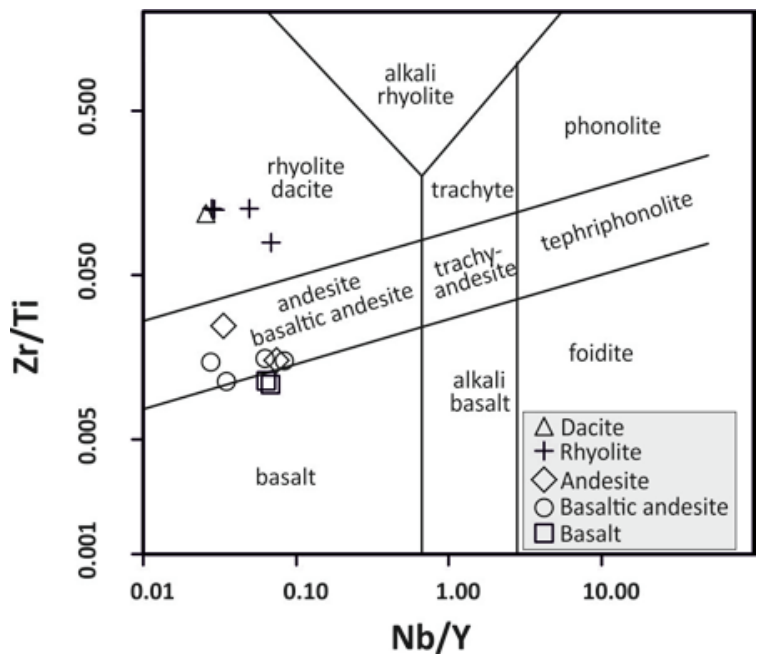

Figure 5. Rock classification diagram based on $\mathrm{Nb} / \mathrm{Y}$ vs $\mathrm{Zr} / \mathrm{Ti}$ (Pearce 1996) for the extrusive rocks from the upper level of Göksun ophiolite

\subsection{Alkali-Silica Reactivity}

For pointing out the alkali-silica potential of the volcanic rocks from the upper level of Late Cretaceous suprasubduction-type Göksun ophiolite; the rocks possibly represent lithologically and chemically different rocks according to their colours, were collected from the field. In ASTM C1260 testing, the excessive expansion of the bars in the $\mathrm{NaOH}$ solution (more than $0.20 \%$ after 14 days of soaking) are interpreted as reactive by means of ASR. If the expansion rates of the mortar bars are between $0.10 \%$ and $0.20 \%$; the aggregates which were used to prepare those mortar bars can be evaluated as both innocuous or deleterious (Farny and Kerkhoff, 2007)

The tested aggregates representing the different lithological units of the volcanics from the Göksun ophiolite show different expansion ratios changing from $0,01 \%$ to $0,29 \%$ (Table 3 ). In general basic rocks show less expansion than intermediate and acidic volcanic rock units of the Göksun ophiolite.

Table 3. The expansion ratios of the volcanic aggregates after 14 days Accelerated mortar bar method

\begin{tabular}{ccccccc}
\hline Rock & \multicolumn{2}{c}{ Basalt } & \multicolumn{4}{c}{ Basaltic andesite } \\
\hline $\begin{array}{c}\text { Samp. } \\
\text { No }\end{array}$ & T9 & T13 & T4 & T7 & T18 & T21 \\
Exp (\%) & 0,03 & 0,01 & 0,12 & 0,29 & 0,20 & 0,10
\end{tabular}

\begin{tabular}{|c|c|c|c|c|c|c|c|}
\hline Rock & \multicolumn{2}{|c|}{ Andesite } & \multicolumn{4}{|c|}{ Rhyolite } & Dacite \\
\hline $\begin{array}{c}\text { Samp. } \\
\text { No }\end{array}$ & T2 & T20 & T14 & T17 & T23 & T24 & T22 \\
\hline $\operatorname{Exp}(\%)$ & 0,17 & 0,05 & 0,06 & 0,01 & 0,09 & 0,06 & 0,01 \\
\hline
\end{tabular}

\section{Discussion and Conclusions}

Number of studies show the andesitic rocks as ASRreactive (Tuthill, 1982; Swamy, 1992;Adam, 2004; Thomas et al., 2007; Kawabata et al., 2008, Ikeda et al., 2008, Islam and Ghafoori, 2013, Shahidul Islam and Akhtar Akhtar, 2013. Kawabata et al., 2008 evaluated the ASR potential of andesitic aggregates derived from crushed stone quarries in Japan and concluded that the reactivity of andesites depends mainly on the composition of pore space solution and dissolution behavior. On the other hand, they implied that even if they have such an environment that alkali supply is higher than normal, the glassy andesites are innocuous by means of ASR.

To point out the alkali-silica reactivity potential of the different aggregates derived from the volcanic section of the late Cretaceous Göksun ophiolite in the northern part of Kahramanmaraş in SE Anatolia, a number of studies such as field, geochemistry, petrography and ASR testing were 
caried out. Both Geochemical and Petrographical investigations indicate the existence of five different lithological units in the volcanic section of Göksun ophiolite such as basalt, basaltic-andesite, andesite, Rhyolite and dacite. As a result of 14 days accelerated mortar bar test for ASR reaction; the measured expansion ratios are from $0,01 \%$ to 0,03 $\%$ in basalts; from $0,10 \%$ to $0,29 \%$ in basaltic andesites; from $0,05 \%$ to $0,17 \%$ in andesites, from 0,01 to $0,09 \%$ in rhyolites, and $0,01 \%$ in a dacite sample (Table 3; Figure 6).

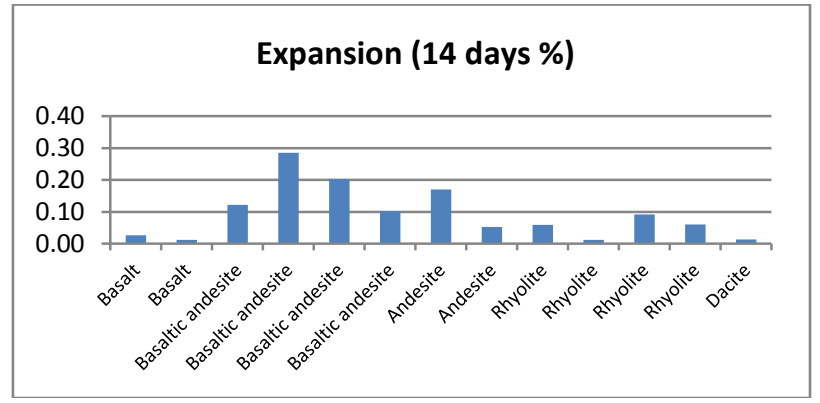

Figure 6. Expansion ratios of the mortar bars produced from volcanic rocks of Göksun ophiolite according to accelerated mortar bar method

According to ASTM C1260 ASR testing methods, if the expansion ratios of the bars exceed $0.20 \%$ after 14 days of soaking, the aggregates are considered as potantially reactive. On the other hand, the expansion ratios of less than $0.10 \%$ are generally evaluated as innocuous aggregate. Expansion between $0.10 \%$ and $0.20 \%$ can be both innocuous and deleterious (Farny and Kerkhoff, 2007).

The accelerated mortar bar method ASR testing results clearly indicate that basaltic andesites and andesites are more prone to be ASR-reactive than basalts and acidic units (rhyolite and dacite) (Table 3 , Figure 6).

The results of ASR tests on basic (basalt) and acidic (rhyolite and dacite) volcanic rocks are out of the hazardous area, ranging from $0.01 \%$ to $0.09 \%$, and the amounts of expansion are very close to each other (Table3, Figure 6). For this reason, it is not possible to establish a correlation between the major element chemistry results and the expansion ratios. However, there are considerable differences in the rate of expansion in intermediate rocks (basaltic andesite and andesite), some within the boundary, and others within the hazardous area.
Thus, the results of the ASR test are suitable for correlation with the major element content. In this context, the highest rate of expansion in basaltic andesites was measured in the sample T-7 $(0,29 \%)$ and the lowest in the sample T-21 $(0,10 \%)$. In andesitic volcanics, the highest expansion value was measured in the sample of T-2 $(0,17 \%)$ and the lowest value in the sample of T-20 (0,05\%) (Table 3, Figure 6). $\mathrm{SiO}_{2}, \mathrm{TiO}_{2}, \mathrm{Al}_{2} \mathrm{O}_{3}, \mathrm{Na}_{2} \mathrm{O}$ and $\mathrm{K}_{2} \mathrm{O}$ values show positive correlation with the amounts of expansion in the andesite and basaltic andesites, and yielded the highest and lowest values in the same samples (Table 2, Table 3). In contrast, the inverse relationship is observed between total iron oxide $\left(\mathrm{FeO}{ }^{*}\right.$ ) and expansion rates (Table 2, Table $3)$. There is no significant correlation between the concentrations of the other major oxides ( $\mathrm{MnO}$, $\mathrm{MgO}, \mathrm{CaO}$ and $\mathrm{P} 2 \mathrm{O5}$ ) and expansion rates in both intermediate volcanic rock units (Table 2, Table 3).

Petrographically, rather than the main mineral phases, It is estimated that the groundmass material has major role on the Alkali-Silica reactivity (Wakizaka, 2000). Thus, the glassy matrix of andesites and basaltic andesites seems to be responsible for the higher expansion ratios than the basic and acidic rocks.

The study show that the intermediate rocks from the upper level of Göksun ophiolite such as andesite and basaltic andesite most probably prone to be involved in alkali-silica reaction with the alkali components of the cement. Before using the aggregates of the volcanic units of late Cretaceous Göksun ophiolite in concrete, a thorough investigation on petrographical characteristics will help to pre-estimate the ASR potential of the aggregates.

\section{Acknowledgements}

The author thanks to Assoc. Prof. Dr. Tamer Koralay for helping to perform the geochemical analysis and preparation of petrographical thin sections in Pamukkale University-Denizli. Fatma Bucak is also thanked for her kind help during the Alkali-Silica reactivity (ASR) tests. 


\section{References}

Adam, J. T., 2004. Potential concrete aggregate reactivity in northern Nevada (Master's thesis paper). UMI Microform Number: 1420180, University of Nevada, Reno, NV.

ASTM C1260-07.,2009. Standard Test Method forPotential Alkali Reactivity of Aggregates (MortarBarMethod), 2009 ASTM Annual Book of Standards, Volume 04.02, Concrete and Aggregates, ASTM International, West Conshohocken, Pennsylvania,

Binici, H., Temiz, H., Sevinç, A.H., Eken,M., Kara, M., and Şayir, Z., 2013. Alüminyum Talaşı, Bims ve Gazbeton Tozu İçeren Betonların Yüksek Sıcaklık Etkisinin incelenmesi. Electronic Journal of Construction Technologies, 9(1),1-15

Çopuroğlu, O., Andiç-Çakır, Ö., Broekmans, M.A.T.M., and Kühnel, R., 2009. Mineralogy, geochemistry and expansion testing of an alkali-reactive basalt from western Anatolia, Turkey. Materials Characterization, 60, 756-766.

Farny, J. And Kerkhoff, B., 2007. Diagnosis and Control of Alkali-Aggregate Reactions in Concrete, IS413, Portland Cement Association, Skokie, Illinois, USA,2007, 26 pages.

Grattan-Bellew, P.E., Beaudoin, J.J. and Valle'e, V.G., 1998. Effect of aggregate particle size and composition on expansion of mortar bars due to delayed ettringite formation, Cem. Concr. Res. 28 (8), 1147-1156.

Ikeda, T., Kawabata, Y., Hamada, H., and Sagawa, Y., 2008. Alkali-silica reactivity of andesite in $\mathrm{NaCl}$ saturated solution. Proceedings of the International Conference on Durability of Concrete Structures, 1, 563-569.

Islam, M. S., Ghafoori, N., 2013. Evaluation of AlkaliSilica Reactivity Using Aggregate Geology, Expansion Limits of Mortar Bars and Concrete Prisms, and Kinetic Model. Journal of Materials Science Research. 2(2):103-117.

Juteau, T., 1980. Ophiolites of Turkey. Ophioliti, 2, 199205.

Katayama, T., St John, D. A. and Futagawa, T., 1989. The petrographic comparison of rocks from Japan and New Zealand-Potential reactivity related to interstitial glass and silica minerals, in: K. Okada, S. Nishibayashi, M. Kawamura (Eds.), 8th International Conference on Alkali- Aggregate Reaction, Elsevier, London,, pp. 537-541.

Kawabata, Y Yamada,K., Matsushita, H., 2008. Alkalisilica reactivity and expansion of mortar incorporating glassy andesite in alkaline solution, in: M.A.T.M. Broekmans, B.J. Wigum (Eds.), Proceedings of the 13th International Conference on Alkali-
Aggregate Reaction in Concrete (ICAAR), Trondheim, Norway, pp. 874-883.

Ketin, İ., 1983. Türkiye Jeolojisine Genel Bir Bakış. İÜ Kütüphanesi,1259, 595s.

Korkanç, M. and Tuğrul, A., 2005. Evaluation of selected basalts from the point of alkali-silica reactivity. Cement and Concrete Research 35, 505- 512

Marfil, S.A. and Maiza, P.J., 2001. Deteriorated pavements due to the alkali- silica reaction: A petrographic study of three cases in Argentina, Cem. Concr. Res. 31 (7), 1017- 1021.

MTA, 2002. 1/500.000 Türkiye Jeoloji Haritası. General Directorate of Mineral Research and Exploration, Ankara, Turkey.

Parlak, O.,Höck, V., Kozlu, H. And Delaloye, M.2004. Oceanic crust generation in an island arc tectonic setting, SE Anatolian Orogenic Belt (Turkey).Geological Magazine, 141, 583-603

Pearce, J.A., 1996. A users guide to basalt discrimination diagrams. In: Wyman, D.A.(ed.), Trace element geochemistry of volcanic rocks: applications for massive sulphide exploration. Geological Association of Canada, ShortCourse Notes, 12, 79-113.

Rızaoğlu, T., Parlak, O. and İşler, F., 2005. Geochemistry and tectonic significance of Esence granitoid (Göksun-Kahramanmaraş), SE Turkey. Yerbilimleri, 26, 1-13.

Shahidulislam, M. and Akhtar, S., 2013. A Critical Assessment to the Performance of Alkali-Silica Reaction (ASR) in Concrete. Canadian Chemical Transactions, 1(4), 253-266

St John, D.A., 1988. Alkali- aggregate reaction and synopsis of other data, N.Z. Concr. Constr. 32, 7-14.

Swamy, R. N., 1992. The alkali-silica reaction in concrete. Blackie and Son Ltd., Glasgow, London. http://dx.doi.org/10.4324/9780203332641

Thomas, M. D. A., Fournier, B., Folliard, J., Ideker, J., and Resendez, Y. 2007. The use of lithium to prevent or mitigate alkali-silica reaction in concrete pavements and structures. U.S. Department of Transportation, Publication No. FHWA-HRT-06-133, 47.

Tuthill, L. (1982). Alkali-silica reaction - 40 years later. Concrete International, 32-36.

Yılmaz, Y., 1993. New Evidence and Model on the Evolution of the Southeast Anatolian Orogen. Geological Society of America Bulletin, 105, 251-71.

Yılmaz, Y., 1990. Allochthonous terranes in the Tethyan Middle east: Anatolia and surrounding regions. Philosophical Transactions of Royal Society of London, A 331, 611-24. 
Yılmaz, Y., Yiğitbaş, E., and Genç, Ş.C., 1993. Ophiolitic and metamorphic assemblages of Southeast Anatolia and their significance in the geological evolution of the orogenic belt. Tectonics, 12 (5), 1280-1297.

Wakizaka,Y., 2000. Alkali-silica reacktivity of Japanese rocks, Eng. Geol. 56(1-2), 211-221. 